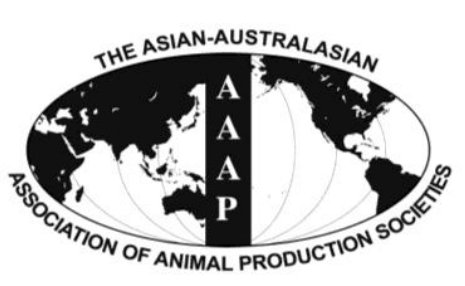

Open Access

Asian Australas. J. Anim. Sci.

Vol. 27, No. 12 : 1763-1772 December 2014

http://dx.doi.org/10.5713/ajas.2014.14063

www.ajas.info

pISSN 1011-2367 elSSN 1976-5517

\title{
The Expression of Carnosine and Its Effect on the Antioxidant Capacity of Longissimus dorsi Muscle in Finishing Pigs Exposed to Constant Heat Stress
}

\author{
Peige Yang ${ }^{\mathrm{a}}$, Yue Hao ${ }^{\mathrm{a}}$, Jinghai Feng, Hai Lin ${ }^{1}$, Yuejin Feng, Xin Wu, Xin Yang ${ }^{1}$, and Xianhong Gu* \\ State Key Laboratory of Animal Nutrition, Institute of Animal Sciences, \\ Chinese Academy of Agricultural Sciences, Beijing, 100193, China
}

\begin{abstract}
The objective of this study was to assess the effects of constant high ambient temperatures on meat quality, antioxidant capacity, and carnosine expression in longissimus dorsi muscle of finishing pigs. Castrated 24 male DLY (crossbreeds between LandracexYorkshire sows and Duroc boars) pigs were allocated to one of three treatments: constant ambient temperature at $22^{\circ} \mathrm{C}$ and $a d$ libitum feeding $(\mathrm{CON}, \mathrm{n}=8)$; constant high ambient temperature at $30^{\circ} \mathrm{C}$ and ad libitum feeding $(\mathrm{H} 30, \mathrm{n}=8)$; and constant ambient temperature at $22^{\circ} \mathrm{C}$ and pair-fed with $\mathrm{H} 30(\mathrm{PF}, \mathrm{n}=8)$. Meat quality, malondialdehyde (MDA) content, antioxidant capacity, carnosine content, and carnosine synthetase (CARNS1) mRNA expression in longissimus dorsi muscle were measured after three weeks. The results revealed that $\mathrm{H} 30$ had lower $\mathrm{pH}_{24 \mathrm{~h}}$, redness at $45 \mathrm{~min}$, and yellowness at $24 \mathrm{~h}$ post-mortem ( $\left.\mathrm{p}<0.05\right)$, and higher drip loss at $48 \mathrm{~h}$ and lightness at $24 \mathrm{~h}$ post-mortem $(\mathrm{p}<0.01)$. Constant heat stress disrupted the pro-oxidant /antioxidant balance in longissimus dorsi muscle with higher MDA content $(\mathrm{p}<0.01)$ and lower antioxidant capacity $(\mathrm{p}<0.01)$. Carnosine content and CARNS1 mRNA expression in longissimus dorsi muscle of $\mathrm{H} 30$ pigs were significantly decreased $(\mathrm{p}<0.01)$ after three weeks at $30^{\circ} \mathrm{C}$. In conclusion, constant high ambient temperatures affect meat quality and antioxidant capacity negatively, and the reduction of muscle carnosine content is one of the probable reasons. (Key Words: Heat Stress, Meat Quality, Antioxidants, Carnosine, Pigs)
\end{abstract}

\section{INTRODUCTION}

High ambient temperatures affect livestock production (Lin et al., 2006; Lu et al., 2007). Heat stress has negative effects on growth performance, feed intake and body weight gain (Morales et al., 2014), contributing to high mortality rates in pigs. Acute heat stress and transport stress accelerate the development of rigor mortis (McKee and Sams, 1997), which results in low $\mathrm{pH}$, high $\mathrm{L}^{*}$ values, and PSE-pale, soft, and exudative-meat characteristics in pigs and chickens. With the global greenhouse effect, high ambient temperatures have negatively impacted on

\footnotetext{
* Corresponding Author: Xianhong Gu. Tel: +86-10-62815895, Fax: +86-10-62815895, E-mail: guxianhong@vip.sina.com

1 Department of Animal Science, Shandong Agricultural University, Taian, Shandong 271018, China.

${ }^{a}$ These authors contributed equally.

Submitted Jan. 24, 2014; Revised Apr. 12, 2014; Accepted Jun. 23, 2014
}

livestock production. Recent studies have focused on the effects of acute or short-time stress on growth performance and meat quality of pigs (Pérez et al., 2002), broilers (Lu et al., 2007), and sheep (Chulayo et al., 2013). However, few studies have focused on the effects of constant heat stress on meat quality and antioxidant capacity of finishing pigs.

Several vertebrate species counteract heat-induced damage with their antioxidant defense system (Antonopoulou et al., 2013), which consists of superoxide dismutase (SOD), catalase (CAT), and glutathione peroxidase. Heat stress shifts the antioxidant-free radical equilibrium towards more free radicals (Imik et al., 2012). It has been reported that heat stress is responsible for higher levels of reactive oxygen species (ROS; Lin et al., 2006) and disturbances in the pro-oxidant and antioxidant defense balance. Muscle antioxidant capacity has a positive correlation with meat quality. Oxidation in muscle tissue is evident by increased conversion of myoglobin, a red muscle 
pigment, to metmyoglobin, a brown pigment, and the development of rancid odors and flavors from the degradation of polyunsaturated fatty acids (Velasco et al., 2011).

Carnosine is involved in the antioxidant system. Carnosine supplementation improves the antioxidant capacity and meat quality of pigs (Ma et al., 2010). In rats exposed to chronic cold stress, carnosine supplementation improves the pro-oxidant/antioxidant balance (Kalaz et al., 2012). Higher carnosine levels in response to short-term stress have been observed in breast and thigh tissues of broilers (Manhiani et al., 2011). However, few studies have focused on the effects of carnosine on the meat quality and antioxidant capacity of longissimus dorsi (LD) muscle in finishing pigs under constant heat stress. In view of previous reports, we hypothesize that muscle carnosine is crucial for the pro-oxidant/antioxidant balance of $\mathrm{LD}$ muscle in finishing pigs exposed to chronic heat stress.

In this study, the effects of constant heat stress on meat quality, carnosine content and muscle oxidant status in finishing pigs were investigated. Furthermore, we proposed the hypothesis that carnosine may affect pork quality by the pro-oxidant/antioxidant balance in LD muscle of finishing pigs.

\section{MATERIALS AND METHODS}

\section{Animals and experimental design}

The experiment was performed in accordance with Chinese guidelines for the use of experimental animals and animal welfare (Science and Technology Ministry of China, 2006). Twenty-four castrated male DLY (crossbreeds between LandracexYorkshire sows and Duroc boars) pigs were selected from eight litters (body weight: $79.0 \pm 1.5 \mathrm{~kg}$ ) from a pig breeding farm in Beijing, China, among which three pigs from each litter were allocated to one of three treatments: constant ambient temperature at $22^{\circ} \mathrm{C}$ and $\mathrm{ad}$ libitum feeding (CON, $\mathrm{n}=8)$; constant high ambient temperature at $30^{\circ} \mathrm{C}$ and ad libitum feeding $(\mathrm{H} 30, \mathrm{n}=8)$; and constant ambient temperature at $22^{\circ} \mathrm{C}$ and pair-fed with the diet consumed by $\mathrm{H} 30(\mathrm{PF}, \mathrm{n}=8)$. Prior to the experiment, the animals were allowed to acclimatize at $22^{\circ} \mathrm{C}$ for seven days in an environmental control chamber. The experimental period lasted three weeks. During the study, the pigs were individually caged (cage dimensions: $150 \times 80 \times 80 \mathrm{~cm}$ ) with 14 -h light and 10 -h dark cycles and $55 \pm 5 \%$ relative humidity. The animals had ad libitum access to water. Feed consisted of a fattening diet (corn-soybean meal) containing $15.73 \%$ crude protein and $13.39 \mathrm{MJ} / \mathrm{kg}$ digestible energy.

\section{Samples and sample processing}

Pigs were stunned by an electrical input $(220 \mathrm{~V}$, alternating current, $50 \mathrm{~Hz}$ for $10 \mathrm{~s}$ ) following a 12-h overnight fast, and all the sampling processes on each carcass were completed within 15 min. Longissimus dorsi muscle tissues from the 10th thoracic vertebra of the right carcass were snap-frozen in liquid nitrogen and stored at $-80^{\circ} \mathrm{C}$ for enzyme activity, real-time polymerase chain reaction (PCR) and high performance liquid chromatography-mass spectrometry (HPLC-MS) analyses. Longissimus dorsi muscles from the 4th and 10th thoracic vertebra of the left carcass were quickly separated and stored at $4^{\circ} \mathrm{C}$ in $45 \mathrm{~min}, 24 \mathrm{~h}$, and $48 \mathrm{~h}$ for meat quality measurements.

\section{Meat quality measurements}

Longissimus dorsi samples from the 10th and 12th thoracic vertebra were used for $\mathrm{pH}$ and meat color measurements. The $\mathrm{pH}$ values were determined 45-min post-mortem $\left(\mathrm{pH}_{45 \mathrm{~min}}\right)$ and $24-\mathrm{h}$ and 48 -h post-storage at $4^{\circ} \mathrm{C}$ in self-sealed plastic bags $\left(\mathrm{pH}_{24} \mathrm{~h}\right.$ and $\mathrm{pH}_{48} \mathrm{~h}$, respectively), using a portable $\mathrm{pH}$ meter ( $\mathrm{pH}-\mathrm{STAR}$, R.Matthaus, Berlin, Germany) equipped with a spear-type electrode. At 45-min and 24-h post-mortem, meat color was measured with the Chroma meter CR-410 (Minolta, Tokyo, Japan). Color was reported in the CIE-LAB (Commission internationale de l'Éclairage color space) trichromatic system, i.e., $\mathrm{L}^{*}, \mathrm{a}^{*}$, and $\mathrm{b}^{*}$ values $\left(\mathrm{L}^{*}=\right.$ lightness; $\mathrm{a}^{*}=$ redness; and $b^{*}=$ yellowness). Meat color was expressed as the average of the three measurements.

Drip loss was determined by the filter paper method (Kauffman et al., 1986) at $24 \mathrm{~h}$ and $48 \mathrm{~h}$ post-mortem. To measure water holding capacity (WHC), four meat samples from the 4th and 6th thoracic vertebra were weighed (initial weight for drip loss). Samples were placed on a net and suspended in an inflated bag, ensuring there was no contact between the samples and the bags. Following $24 \mathrm{~h}$ and $48 \mathrm{~h}$ of storage at $4{ }^{\circ} \mathrm{C}$, two samples were removed from the bag, blotted dry, and weighed (ultimate weight). Drip loss was calculated by the following equation, drip loss $(\%)=($ initial weight $[\mathrm{g}]-$ ultimate weight $[\mathrm{g}]) /$ initial weight $(\mathrm{g}) \times 100 \%$.

The shear force of samples from the 6th and 9th thoracic vertebra was measured according to Chinese agricultural standard NY/T-1180-2006. Pork chops from each sample were stored at $4^{\circ} \mathrm{C}$ for $24 \mathrm{~h}$, individually cooked in plastic bags in a water bath $\left(80^{\circ} \mathrm{C}\right)$ to an internal temperature of $70^{\circ} \mathrm{C}$, and cooled to room temperature. After cooking, four cores $(1.27 \mathrm{~cm}$ diameter) parallel to the longitudinal orientation of the muscle fibers were removed from each pork chop for shear force measurements. Shear force was measured with a TMS-Pro (Food Technology Corporation, Sterling, VA, USA) and expressed in Newton. The samples were sheared perpendicular to the long axis of the core. 


\section{Antioxidant indexes in longissimus dorsi muscle}

Assay kits for protein, lactate, lactate dehydrogenase (LDH), malondialdehyde (MDA), SOD, and CAT were obtained from Nanjing Jiancheng Bioengineering Institute (Nanjing, China; corresponding catalog Numbers are A0452, A019-2, A020-2, A003-1, A001-1, and A007-2). Muscle homogenates were centrifuged at $600 \times g$ for $10 \mathrm{~min}$ at $4{ }^{\circ} \mathrm{C}$ to remove crude fractions, and the resulting supernatants were used for the determination of enzymatic content and activities by spectrophotometric methods using a spectrophotometer (SP752, Shanghai Spectrum, Shanghai, China). All of the assays followed the instructions of the kits. Muscle protein was measured by the method of coomassie brilliant blue and detected at $595 \mathrm{~nm}$. Muscle lactate content was measured using an assay including LDH. The levels of MDA in longissimus dorsi muscle were determined with 2-thiobarbituric acid according to Placer et al. (1966) at $532 \mathrm{~nm}$. The CAT was assayed with the initial rate of hydrogen peroxide decomposition at $405 \mathrm{~nm}$ (Aebi, 1984). The SOD activity was determined by the xanthine oxidase method described by Ōyanagui (1984). The activity of LDH was measured spectrophotometrically at $450 \mathrm{~nm}$ within the $\mathrm{LDH}$-catalyzed reduction of pyruvate to lactate (Jurie et al., 2006). The MDA level was expressed as nanomoles per milligram of protein, and the enzyme activity was expressed as unit per milligram protein.

\section{Carnosine content in longissimus dorsi muscle}

Carnosine extraction: Approximately $30 \mathrm{mg}$ of LD muscle was transferred to Eppendorf tubes, homogenized, and extracted with $1 \mathrm{~mL}$ of methanol/water (50:50) for 30 min in an ultrasonic bath (Beat Ultrasonic, Zhangjiagang, China). Following centrifugation at $16,000 \times \mathrm{g}$ for $30 \mathrm{~min}$, the supernatant was passed through a $0.45-\mu \mathrm{m}$ membrane filter. The water-extracted filtrate (supernatant) was subjected to heat treatment at $80^{\circ} \mathrm{C}$ for $15 \mathrm{~min}$ in a water bath (model no. 283, Thermo Scientific, USA), immediately cooled and centrifuged at $6,000 \times \mathrm{g}$ for $20 \mathrm{~min}$ at $25 \pm 4^{\circ} \mathrm{C}$ to remove precipitated proteins. The resulting supernatant was collected and stored at $-80^{\circ} \mathrm{C}$.

Carnosine determination by HPLC-MS: Sample aliquots $(5 \mu \mathrm{L})$ were subjected to chromatography in a C18 column (150 mm×4.6 mm; Waters Corp, Milford, MA, USA) at 0.8 $\mathrm{mL} / \mathrm{min}$ and $50^{\circ} \mathrm{C}$. The mobile phase consisted of $0.1 \%$ heptafluorobutyric acid $+0.1 \%$ formic acid in water (A) and $0.1 \%$ heptafluorobutyric acid $+0.1 \%$ formic acid in acetonitrile (B). Elution was performed during $20 \mathrm{~min}$ : $90 \%$ A for $5 \mathrm{~min}, 90 \%$ to $70 \%$ A for $2 \mathrm{~min}, 70 \%$ to $65 \%$ A for 3 $\min , 65 \%$ to $5 \%$ A for $5 \mathrm{~min}, 5 \%$ to $0 \%$ A for $0.5 \mathrm{~min}$, and $90 \%$ A for 4.5 min.

Mass spectrometry was performed on a API 4000 QQQ (Applied Biosystems, Carlsbad, CA, USA) coupled to an HPLC system (LC20A, Shimadzu Instruments, Kyoto, Japan) operating in positive-ion mode. A standard curve was generated with different concentrations (5 to 1,000 $\mathrm{mM}$ ) of pure carnosine (C9625, Sigma-Aldrich, St. Louis, MO, USA). The resulting linear regression was $y=$ $0.000132 \mathrm{x}-3.45 \mathrm{e}^{-5} \quad(\mathrm{r}=0.9935)$, of which $\mathrm{x}$ means carnosine concentration, y means mass spectrum response. The retention times and peak areas were analyzed by API analyst 1.5 software (LC20A, Shimadzu Instruments, Kyoto, Japan). Carnosine concentration was calculated from the standard curve.

\section{RNA isolation and real-time polymerase chain reaction analysis}

Total RNA was isolated from $20 \mathrm{mg}$ skeletal muscle tissue using Ultrapure RNA extraction kit (Cat\# CW0581, CWbio, Beijing, China). RNA integrity was assessed by $1 \%$ agarose gel electrophoresis, which revealed intact bands corresponding to $18 \mathrm{~S}$ and $28 \mathrm{~S}$ ribosomal RNA subunits. Following RNase-free DNase treatment, RNA was reversetranscribed using HiFi-MMLV cDNA first strand synthesis kit (Cat\#CW0744, CWbio, China). The gene-specific primer pairs used in this experiment are shown in Table 1. Quantitative RT-PCR was performed in duplicate in an ABI Prism 7500 apparatus (Applied Biosystems, USA). In this experiment, cDNA was amplified by PCR with genespecific primer pairs using Ultra SYBR Mixture with ROX (\#CW0956, CWbio, China). Real-time PCR data were analyzed using the delta-delta $C_{T}$ method, i.e., $2^{-\Delta \Delta C T}$ method (Schmittgen and Livak, 2008). The primers designed for the reference genes were based on sequences published in Genbank (http://www.ncbi.nlm. nih.gov/) and are shown in Table 1.

\section{Statistical analyses}

Comparisons among the three experimental treatments

Table 1. Primer sequences, product size of real-time polymerase chain reaction

\begin{tabular}{llccc}
\hline Primers & \multicolumn{1}{c}{ Primer sequences } & $\begin{array}{c}\text { GeneBank accession } \\
\text { number }\end{array}$ & $\begin{array}{c}\text { Annealing temperature } \\
\left({ }^{\circ} \mathrm{C}\right)\end{array}$ & $\begin{array}{c}\text { Product size } \\
(\mathrm{bp})\end{array}$ \\
\hline CARNS1 & F :CCAAGCAGAAGAGCCGTACCCA & XM_005660632.1 & 84.45 & 83 \\
& R:GGGCACAGCATAGAGGGAGGG & & & \\
$\beta$-actin & F:ATCCAGGCAGTGCTGTCCCTCTAC & XM_005670976.1 & 88.14 & 110 \\
& R:GGCAGCGCGTAGCCCTCATA & & & \\
\hline
\end{tabular}

CARNS1, carnosine synthetase.

For each reference gene, gene name, GenBank accession number, primer sequences, Tm values are indicated. 
Table 2. Effects of constant heat stress on meat color of longissimus dorsi muscle in finishing pigs

\begin{tabular}{llccccc}
\hline Post-mortem time & Items & CON & H30 & PF & SEM & p-value \\
\hline $45 \mathrm{~min}$ & $\mathrm{~L}^{*}$ & $44.37^{\mathrm{B}}$ & $45.73^{\mathrm{A}}$ & $44.20^{\mathrm{B}}$ & 0.29 & $<0.01$ \\
& $\mathrm{a}^{*}$ & $17.86^{\mathrm{a}}$ & $16.44^{\mathrm{b}}$ & $16.83^{\mathrm{ab}}$ & 0.37 & 0.03 \\
& $\mathrm{~b}^{*}$ & 5.61 & 5.04 & 4.43 & 0.35 & 0.08 \\
$24 \mathrm{~h}$ & $\mathrm{~L}^{*}$ & $50.68^{\mathrm{B}}$ & $52.32^{\mathrm{A}}$ & $49.58^{\mathrm{C}}$ & 0.20 & $<0.01$ \\
& $\mathrm{a}^{*}$ & 21.85 & 20.70 & 21.33 & 0.38 & 0.13 \\
& $\mathrm{~b}^{*}$ & $12.37^{\mathrm{a}}$ & $11.38^{\mathrm{b}}$ & $11.27^{\mathrm{b}}$ & 0.27 & 0.02 \\
\hline
\end{tabular}

CON, constant ambient temperature at $22^{\circ} \mathrm{C}$ and ad libitum feeding; $\mathrm{H} 30$, constant high ambient temperature at $30^{\circ} \mathrm{C}$ and ad libitum feeding; $\mathrm{PF}$, constant ambient temperature at $22^{\circ} \mathrm{C}$ and pair-fed to the $\mathrm{H} 30$ pigs; SEM, standard error of the mean; $\mathrm{L}^{*}$, lightness $(n=8)$; $a^{*}$, redness $(n=8)$; $b^{*}$, yellowness $(n=$ 8)

A,B,C Treatments with different superscript capital letters in the same row are different at $\mathrm{p}<0.01$.

a,b,c Treatments with different superscript low letters in the same row are different at $\mathrm{p}<0.05$

(CON, H30, and PF) were performed with the one-way analysis of variance (SAS Institute, 2003, USA); significant means were analyzed with Duncan's multiple range tests. Correlation analyses among meat quality index were performed by Pearson's linear regression test (SAS Institute, 2003, USA). Statistical significance was set at $p<0.05$ and $\mathrm{p}<0.01$

\section{RESULTS}

Effects of constant heat stress on meat quality of longissimus dorsi muscle

The effects of constant heat exposure on $\mathrm{pH}$, color, drip loss, and shear force of LD muscle are shown in Table 2 and 3. At 45 min post-mortem, $\mathrm{H} 30$ had higher $\mathrm{L}^{*}$ values than CON and PF pigs $(\mathrm{p}<0.01)$, and $\mathrm{a}^{*}$ values decreased $(\mathrm{p}<0.05)$ in $\mathrm{H} 30$ compared to CON. The PF had lower b* values than $\mathrm{CON}(\mathrm{p}<0.1)$. At $24 \mathrm{~h}$ post-mortem, $\mathrm{H} 30$ had higher $L^{*}$ values $(p<0.01)$ than $C O N$, while the $L^{*}$ values of $\mathrm{CON}$ were higher than PF, PF had the lowest $\mathrm{L}^{*}$ values $(\mathrm{p}<0.01)$ among all treatments. At $24 \mathrm{~h}$ post-mortem, H30 and PF pigs had lower $b^{*}$ values relative to CON $(p<0.05)$. There were no significant differences in $\mathrm{a}^{*}$ values among the treatments at $24 \mathrm{~h}$ post-mortem.

There were no differences in muscle $\mathrm{pH}_{45}$ min among treatments $(\mathrm{p}>0.05)$. The $\mathrm{pH}_{24 \mathrm{~h}}$ values of $\mathrm{H} 30$ and $\mathrm{PF}$ were significantly lower than those of $\mathrm{CON}(\mathrm{p}<0.01) ; \mathrm{pH}_{48}$ values of $\mathrm{H} 30$ and PF were slightly lower than those of $\mathrm{CON}(\mathrm{p}<0.1)$. The $\mathrm{pH}$ values of LD muscle decreased with storage up to $48 \mathrm{~h}$ post-mortem. In terms of WHC, H30 had higher drip loss than $\mathrm{CON}$ and $\mathrm{PF}$ at $48 \mathrm{~h}$ post-mortem $(p<0.01)$. There were no significant differences in drip loss among the treatments at $24 \mathrm{~h}$ post-mortem. Higher drip loss was observed with increasing storage ( $24 \mathrm{~h}$ vs $48 \mathrm{~h}$ ). Shear force values in $\mathrm{H} 30$ were significantly higher than those in $\mathrm{CON}$ and $\mathrm{PF}(\mathrm{p}<0.01)$

According to the results, constant heat stress had significant effects on meat color: high $\mathrm{L}^{*}$ values at $45 \mathrm{~min}$ and $24 \mathrm{~h}$, low a* values at $45 \mathrm{~min}$, and low $\mathrm{b}^{*}$ values at 24 h. Constant heat stress reduced muscle $\mathrm{pH}$ at $24 \mathrm{~h}$ and $48 \mathrm{~h}$ post-mortem, with similar tendencies in PF pigs, which suggests that the reduction in $\mathrm{pH}$ might be attributed to feed restriction. Higher drip loss at $48 \mathrm{~h}$ and shear force values were observed in pigs under constant heat stress.

\section{Effects of constant heat stress on carnosine synthetase mRNA expression and carnosine content of longissimus dorsi muscle}

Carnosine synthetase (CARNS1) mRNA expression in H30 of LD muscle was down-regulated compared to that in $\mathrm{PF}$ and CON ( $<<0.01$; Figure 1). There was a 0.53 -fold down-regulation in CARNS1 mRNA expression in $\mathrm{H} 30$ compared to CON in LD muscle. Carnosine content in LD muscle was $4.98 \mathrm{mg} / \mathrm{g}$ in $\mathrm{H} 30,5.62 \mathrm{mg} / \mathrm{g}$ in $\mathrm{CON}$, and 5.58

Table 3. Effects of constant heat stress on $\mathrm{pH}$, drip loss and shear force of longissimus dorsi muscle in finishing pigs

\begin{tabular}{lcccccc}
\hline Items $^{1}$ & Post-mortem time & CON & H30 & PF & SEM & p-value \\
\hline pH value & $45 \mathrm{~min}$ & 6.35 & 6.37 & 6.35 & 0.13 & 0.99 \\
& $24 \mathrm{~h}$ & $5.73^{\mathrm{a}}$ & $5.43^{\mathrm{b}}$ & $5.39^{\mathrm{b}}$ & 0.09 & 0.02 \\
\multirow{2}{*}{ Drip loss (\%) } & $48 \mathrm{~h}$ & 5.41 & 5.24 & 5.27 & 0.05 & 0.08 \\
& $24 \mathrm{~h}$ & 3.49 & 3.97 & 3.64 & 0.20 & 0.25 \\
Shear force $(\mathrm{N})$ & $48 \mathrm{~h}$ & $5.25^{\mathrm{B}}$ & $6.45^{\mathrm{A}}$ & $5.42^{\mathrm{B}}$ & 0.26 & $<0.01$ \\
\hline
\end{tabular}

CON, constant ambient temperature at $22^{\circ} \mathrm{C}$ and ad libitum feeding; $\mathrm{H} 30$, constant high ambient temperature at $30^{\circ} \mathrm{C}$ and ad libitum feeding; $\mathrm{PF}$, constant ambient temperature at $22^{\circ} \mathrm{C}$ and pair-fed to the $\mathrm{H} 30$ pigs, SEM, standard error of the mean.

${ }^{1} \mathrm{pH}$ value, $\mathrm{n}=8$; Drip loss, $\mathrm{n}=8$; Shear force, $\mathrm{n}=6$.

A,B,C Treatments with different superscript capital letters in the same row are different at $\mathrm{p}<0.01$.

a,b,c Treatments with different superscript low letters in the same row are different at $p<0.05$ 


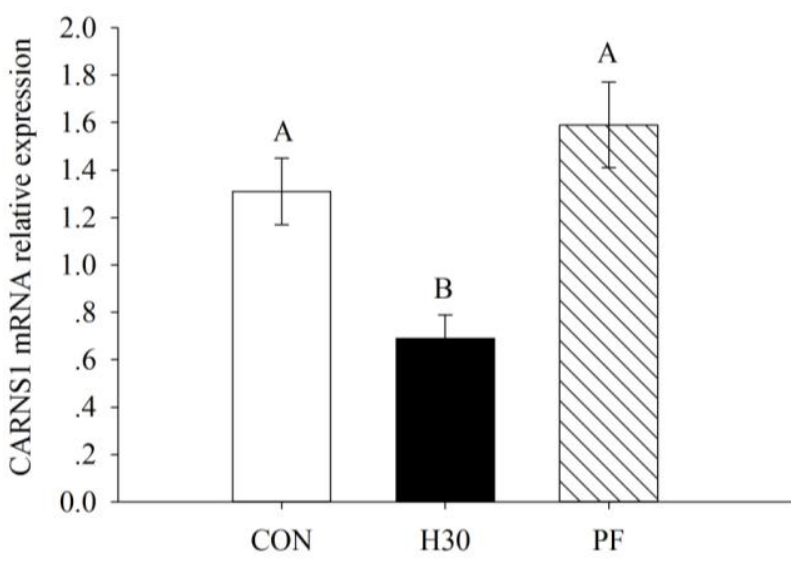

Figure 1. Effects of constant heat stress on carnosine synthetase (CARNS1) mRNA expression of longissimus dorsi muscle in finishing pigs. CARNS1, carnosine synthetase mRNA expression in longissimus dorsi muscle, data analyzed using the $2^{-\Delta \Delta \mathrm{CT}}$ method, $\mathrm{n}=8$; Con, control, $22^{\circ} \mathrm{C}$; $\mathrm{H} 30$, heat stress, $30^{\circ} \mathrm{C}$; $\mathrm{PF}$, pair-fed with $\mathrm{H} 30,22^{\circ} \mathrm{C}$. Capital letters on columns indicate significant levels within columns $(\mathrm{p}<0.01)$.

$\mathrm{mg} / \mathrm{g}$ in PF. As shown in Figure 2, carnosine content in H30 was significantly lower than that in CON or PF $(p<0.01)$. The down-regulation in CARNS 1 mRNA expression was in accordance with the lower carnosine content in $\mathrm{H} 30$.

Effects of constant heat stress on malondialdehyde content and enzymatic activity of longissimus dorsi muscle

The effects of constant heat stress on lactate, MDA content, LDH activity, and antioxidant enzyme activities (SOD and CAT) of LD muscle are shown in Table 4. The H30 pigs had higher muscle lactate content than CON $(\mathrm{p}<0.05)$. Muscle LDH activities in H30 and PF pigs were higher than those in CON ( $p<0.1)$. The MDA content of LD muscle was higher in $\mathrm{H} 30$ than in the other two treatments $(p<0.01)$; MDA content in PF was higher than that in CON $(p<0.01) . \mathrm{H} 30$ and PF pigs had lower muscle SOD activities than CON $(p<0.01)$. The CAT activities in H30 were lower than those in CON and PF $(\mathrm{p}<0.01)$.

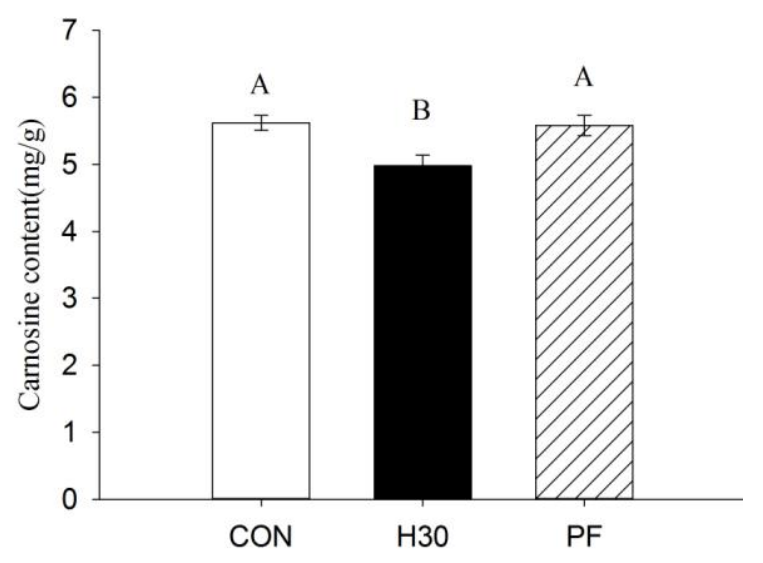

Figure 2. Effects of constant heat stress on carnosine content of longissimus dorsi muscle in finishing pigs. Carnosine content: carnosine content (mg/g) in longissimus dorsi muscle measured by high performance liquid chromatography-mass spectrometry, $\mathrm{n}=$ 8; Con, control, $22^{\circ} \mathrm{C}$; $\mathrm{H} 30$, heat stress, $30^{\circ} \mathrm{C}$; PF, pair-fed with $\mathrm{H} 30,22^{\circ} \mathrm{C}$. Capital letters on columns indicate significant levels within columns $(\mathrm{p}<0.01)$.

Correlations among carnosine content, meat quality, and antioxidant enzyme activities of longissimus dorsi muscle

As shown in Table 5, 6, and 7, carnosine concentration was negatively correlated with $\mathrm{L}^{*}$ values (at $45 \mathrm{~min}$ and 24 $\mathrm{h}$ post-mortem; $\mathrm{p}<0.05)$, drip loss at $48 \mathrm{~h}$ post-mortem $(\mathrm{p}<0.01)$ and MDA content $(\mathrm{p}<0.01)$, and positively correlated with CAT activity $(\mathrm{p}<0.05)$. The $\mathrm{pH}_{24 \mathrm{~h}}$ and $\mathrm{pH}_{48 \mathrm{~h}}$ values of $\mathrm{LD}$ muscle were positively correlated with $\mathrm{a}^{*}$ and $\mathrm{b}^{*}$ values at $24 \mathrm{~h}$ post-mortem $(\mathrm{p}<0.01)$. The $\mathrm{pH}_{48 \mathrm{~h}}$ values of LD muscle were negatively correlated with $\mathrm{L}^{*}$ values at 45 min post-mortem $(\mathrm{p}<0.05)$. The $\mathrm{pH}_{24}$ h values were negatively correlated with drip loss at $24 \mathrm{~h}$ post-mortem $(\mathrm{p}<0.01)$.

Muscle MDA content had significant positive correlations with drip loss at $48 \mathrm{~h}(\mathrm{p}<0.01)$, L*values at 24 $h$, and shear force $(p<0.01)$. The SOD activities were negatively correlated with $\mathrm{L}^{*}$ values at $45 \mathrm{~min}$ and positively correlated with $\mathrm{b}^{*}$ values at $24 \mathrm{~h}$ post-mortem $(\mathrm{p}<0.05)$, while CAT activities were negatively correlated

Table 4. Effects of constant heat stress on enzyme activities of longissimus dorsi muscle in finishing pigs

\begin{tabular}{lccccc}
\hline Items & CON & H30 & PF & SEM & p-value \\
\hline Lactate (mm mol/g protein) & $1.02^{\mathrm{b}}$ & $1.52^{\mathrm{a}}$ & $1.32^{\mathrm{ab}}$ & 0.10 & 0.01 \\
LDH (U/mg protein) & 14.76 & 16.06 & 16.04 & 0.41 & 0.06 \\
MDA (n mol/mg protein) & $0.10^{\mathrm{C}}$ & $0.13^{\mathrm{A}}$ & $0.11^{\mathrm{B}}$ & $<0.01$ & $<0.01$ \\
SOD (U/mg protein) & $11.84^{\mathrm{A}}$ & $9.92^{\mathrm{B}}$ & $9.97^{\mathrm{B}}$ & 0.20 & $<0.01$ \\
CAT (U/mg protein) & $0.49^{\mathrm{A}}$ & $0.41^{\mathrm{B}}$ & $0.48^{\mathrm{A}}$ & 0.01 & $<0.01$ \\
\hline
\end{tabular}

$\mathrm{CON}$, constant ambient temperature at $22^{\circ} \mathrm{C}$ and ad libitum feeding; $\mathrm{H} 30$, constant high ambient temperature at $30^{\circ} \mathrm{C}$ and ad libitum feeding; $\mathrm{PF}$, constant ambient temperature at $22^{\circ} \mathrm{C}$ and pair-fed to the $\mathrm{H} 30$ diets; SEM, standard error of the mean; Lactate, lactate content in longissimus dorsi muscle ( $\mathrm{n}=8$ ); $\mathrm{LDH}$, lactate dehydrogenase activity in longissimus dorsi muscle $(\mathrm{n}=8)$; MDA, malondialdehyde content in longissimus dorsi muscle ( $\mathrm{n}=8$ ); SOD, superoxide dismutase activity in longissimus dorsi muscle $(\mathrm{n}=8)$; CAT, catalase activity in longissimus dorsi muscle $(\mathrm{n}=7)$.

${ }_{A, B, C}$ Treatments with different superscript capital letters in the same row are different at $\mathrm{p}<0.01$.

a,b,c Treatments with different superscript low letters in the same row are different at $\mathrm{p}<0.05$. 
Table 5. Correlation among carnosine content, MDA, SOD, CAT, and pH of longissimus dorsi muscle in finishing pigs

\begin{tabular}{lccccccc}
\hline Index & MDA & SOD & CAT & LDH & $\mathrm{pH}_{45 \text { min }}$ & $\mathrm{pH}_{24 \mathrm{~h}}$ & $\mathrm{pH}_{48 \mathrm{~h}}$ \\
\hline Carnosine & $-0.52^{* *}$ & 0.39 & $0.43^{*}$ & -0.26 & 0.07 & 0.21 & 0.06 \\
\hline
\end{tabular}

MDA, malondialdehyde content in longissimus dorsi muscle $(\mathrm{n}=8)$; SOD, superoxide dismutase activity in longissimus dorsi muscle $(\mathrm{n}=8)$; CAT, catalase activity in longissimus dorsi muscle $(\mathrm{n}=7)$; $\mathrm{LDH}$, lactate dehydrogenase activity in longissimus dorsi muscle $(\mathrm{n}=8)$. $\mathrm{pH}, \mathrm{muscle} \mathrm{pH}(\mathrm{n}=8)$; CARNS1, Carnosine: carnosine content in longissimus dorsi muscle $(\mathrm{n}=7-8$ [correlation between carnosine and CAT, $\mathrm{n}=7$; otherwise $\mathrm{n}=8$ ]).

$* 0.01<\mathrm{p}<0.05 ; * * \mathrm{p}<0.01$. Correlation analysis was performed by a Pearson's linear regression test.

Table 6. Correlation among carnosine content, drip loss, meat color, and shear force of longissimus dorsi muscle in finishing pigs

\begin{tabular}{lccccccccc}
\hline Index & Drip loss 24 h & Drip loss 48 h & $\mathrm{L}^{*} 45 \mathrm{~min}$ & $\mathrm{a}^{*} 45 \min$ & $\mathrm{b}^{*} 45 \mathrm{~min}$ & $\mathrm{~L}^{*} 24 \mathrm{~h}$ & $\mathrm{a}^{*} 24 \mathrm{~h}$ & $\mathrm{~b}^{*} 24 \mathrm{~h}$ & Shear force \\
\hline Carnosine & -0.32 & $-0.58^{* *}$ & $-0.45^{*}$ & 0.15 & -0.22 & $-0.50^{*}$ & 0.18 & -0.02 & -0.42
\end{tabular}

Drip loss $(n=8)$; L*, lightness $(n=8)$; $a^{*}$, redness $(n=8) ; b^{*}$, yellowness $(n=8)$; Shear force $(n=6)$; Carnosine, carnosine content in longissimus dorsi muscle $(n=6-8$ [correlation between carnosine and shear force, $n=6$; otherwise $n=8$ ]).

$* 0.01<\mathrm{p}<0.05 ; * * \mathrm{p}<0.01$. Correlation analysis was performed by a Pearson's linear regression test.

with $\mathrm{L}^{*}$ values (at $45 \mathrm{~min}$ and $24 \mathrm{~h}$ post-mortem; $\mathrm{p}<0.01$ ) and shear force $(\mathrm{p}<0.05)$.

\section{DISCUSSION}

Effects of constant heat stress on meat quality of longissimus dorsi muscle in finishing pigs

Effects of constant heat exposure on pork quality, carnosine content and oxidant capacity of LD muscle in finishing pigs were investigated in the study. To distinguish the direct effects of high ambient temperature from the effects caused by a decrease in feed-intake, a pair-fed treatment at $22^{\circ} \mathrm{C}$ ambient temperature was included in this study. The heat-exposed pigs had higher $\mathrm{L}^{*}$ values and lower $a^{*}$ and $b^{*}$ values than CON. H30 pigs had higher L* values than $\mathrm{PF}$ and $\mathrm{CON}$ at $45 \mathrm{~min}$ and $24 \mathrm{~h}$ post-mortem, revealing the direct effects of high ambient temperature on the muscle lightness. Lower $a^{*}$ and $b^{*}$ values were observed in $\mathrm{H} 30$ compared with $\mathrm{CON}$, no significantly differences were observed among $\mathrm{H} 30$ and PF, suggesting that the decreased feed-intake in $\mathrm{H} 30$ pigs might have contributed to the differences in meat color. Küchenmeister et al. (2000) found more pale pork muscle (higher L* values) in the summer than in the winter. Pre-slaughter exercise decreased $a^{*}$ values compared to non exercised pigs, indicated that pre-slaughter stress affect pork color by less redness (Rosenvold et al., 2003).

Meat color is attributed to carboxymyoglobin, deoxymyoglobin, oxymyoglobin and metmyoglobin. In the presence of oxygen, Myoglobin ( $\mathrm{Mb}$, purplish-red color) is converted into the red-colored oxymyoglobin $\left(\mathrm{MbO}_{2}\right)$, which is gradually oxidized into the dull brown-colored metmyoglobin. These three compounds are very sensitive to oxidation (Mancini et al., 2005). Thus, the results of higher $\mathrm{L}^{*}$ values and lower $\mathrm{a}^{*}$ and $\mathrm{b}^{*}$ values in $\mathrm{H} 30$ pigs may be on account of muscle oxidative status under constant heat stress.

It was found that $\mathrm{H} 30$ and PF pigs had the same tendency of decreased muscle $\mathrm{pH}$ values at $24 \mathrm{~h}$ and $48 \mathrm{~h}$ post-mortem, suggesting that the phenomenon may be due to the reduction of feed-intake under constant heat stress. The lower $\mathrm{pH}_{24} \mathrm{~h}$ and $\mathrm{pH}_{48} \mathrm{~h}$ values in $\mathrm{H} 30$ are in accordance with the results obtained in pigs under per-slaughter or chronic heat stress (Salmi et al., 2012; Lu et al., 2010). Stress or exercise before slaughter resulted in faster $\mathrm{pH}$ decline. The $\mathrm{pH}$ value of $\mathrm{LD}$ muscle in finishing pigs

Table 7. Correlation among malondialdehyde (MDA), superoxide dismutase (SOD), catalase (CAT), and drip loss, meat color, shear force of longissimus dorsi muscle in finishing pigs

\begin{tabular}{lccccccccc}
\hline Index & Drip loss $24 \mathrm{~h}$ & Drip loss $48 \mathrm{~h}$ & $\mathrm{~L}^{*} 45 \mathrm{~min}$ & $\mathrm{a}^{*} 45 \mathrm{~min}$ & $\mathrm{~b}^{*} 45 \mathrm{~min}$ & $\mathrm{~L}^{*} 24 \mathrm{~h}$ & $\mathrm{a}^{*} 24 \mathrm{~h}$ & $\mathrm{~b} * 24 \mathrm{~h}$ & Shear force \\
\hline $\mathrm{pH}_{45 \text { min }}$ & -0.16 & -0.37 & -0.34 & -0.21 & 0.12 & -0.08 & -0.40 & -0.21 & 0.24 \\
$\mathrm{pH}_{24 \mathrm{~h}}$ & $-0.52^{* *}$ & -0.25 & -0.26 & 0.31 & 0.11 & -0.11 & $0.66^{* *}$ & $0.63^{* *}$ & -0.06 \\
$\mathrm{pH}_{48 \mathrm{~h}}$ & -0.30 & -0.22 & $-0.40^{*}$ & $0.48^{*}$ & 0.23 & -0.17 & $0.61^{* *}$ & $0.58^{* *}$ & 0.02 \\
$\mathrm{MDA}$ & 0.26 & $0.53^{* *}$ & $0.48^{*}$ & -0.31 & -0.19 & $0.69^{* *}$ & -0.37 & -0.32 & $0.73^{* *}$ \\
$\mathrm{SOD}$ & -0.11 & -0.38 & $-0.43^{*}$ & 0.40 & 0.16 & -0.12 & 0.19 & $0.47^{*}$ & -0.27 \\
$\mathrm{CAT}$ & -0.34 & -0.40 & $-0.59^{* *}$ & 0.37 & 0.18 & $-0.64^{* *}$ & 0.41 & 0.26 & $-0.62^{*}$ \\
\hline
\end{tabular}

Drip loss, $\mathrm{n}=7-8$ (correlation between drip loss and CAT, $\mathrm{n}=7$; otherwise $\mathrm{n}=8$ ); $\mathrm{L}^{*}$, lightness, $\mathrm{n}=7-8$ (correlation between $\mathrm{L}^{*}$ and CAT, $\mathrm{n}=7$; otherwise $\mathrm{n}=8$ ); $\mathrm{a}^{*}$, redness, $\mathrm{n}=7-8$ (correlation between $\mathrm{a}^{*}$ and CAT, $\mathrm{n}=7$; otherwise $\mathrm{n}=8$ ); $\mathrm{b}^{*}$, yellowness, $\mathrm{n}=7-8$ (correlation between $\mathrm{b}^{*}$ and CAT, $\mathrm{n}=7$; otherwise $\mathrm{n}=8$ ); MDA, malondialdehyde content in longissimus dorsi muscle, $\mathrm{n}=6-8$ (correlation between MDA and shear force, $\mathrm{n}=6$; otherwise $\mathrm{n}=8$ ); SOD, superoxide dismutase activity in longissimus dorsi muscle, $\mathrm{n}=6-8$ (correlation between SOD and shear force, $\mathrm{n}=6$; otherwise $\mathrm{n}=8$ ); CAT, catalase activity in longissimus dorsi muscle, $\mathrm{n}=5-7$ (correlation between CAT and shear force, $\mathrm{n}=5$; otherwise $\mathrm{n}=7$ ); $\mathrm{pH}, \mathrm{n}=6-8$ (correlation between $\mathrm{pH}$ and shear force, $\mathrm{n}=6$; otherwise $\mathrm{n}=8$ ).

$* 0.01<\mathrm{p}<0.05 ; * * \mathrm{p}<0.01$. Correlation analysis was performed by a Pearson's linear regression test. 
decreased gradually with storage (45 min, $24 \mathrm{~h}$, and $48 \mathrm{~h}$ ); this result could be attributed to the accumulation of lactate post-mortem. H30 and PF pigs had higher LDH activities and lactate level in LD muscle, similar to the chronically heat-stressed broilers (Zhang et al., 2012). Therefore, LD muscle of constantly heat-exposed or pair-fed pigs may have more pyruvate converted to lactate, leading to lower $\mathrm{pH}$ values.

Chronic heat stress resulted in poor WHC; similar results have been reported in growing pigs (Lu et al., 2010). The water content of meat is one of the essential quality parameters as it relates to the final yield of end product and is also important in terms of eating (Cheng et al., 2008). The excessive loss of water in H30 pigs had an adverse effect on product appearance and shelf life, which also implied financial loss. The results of this study revealed higher shear force values in $\mathrm{H} 30$ pigs than in $\mathrm{PF}$ or CON pigs, similar to the findings of $\mathrm{Lu}$ et al. (2010), who reported that chronic heat stress decreases meat tenderness in growing swine. Longissimus dorsi muscle of H30 pigs had higher drip loss and shear force than PF, indicating that direct effects of high ambient temperature stress caused the changes instead of relying on the decreased feed-intake.

Muscle $\mathrm{a}^{*}$ and $\mathrm{b}^{*}$ values at $24 \mathrm{~h}$ post-mortem were positively correlated with $\mathrm{pH}_{24 \mathrm{~h}}$ values $(\mathrm{r}=0.66, \mathrm{p}<0.01$ and $r=0.63, p<0.01$, respectively), while muscle $L^{*}$ values at $45 \mathrm{~min}$ post-mortem were negatively correlated with $\mathrm{pH}_{48}$ $\mathrm{h}$ values $(\mathrm{r}=-0.40, \mathrm{p}<0.05)$. Color change was visible to the unaided eye when muscle $\mathrm{pH}$ was less than 6.1 (Abril et al., 2001), which was in agreement with the lower muscle $\mathrm{pH}$ and paler meat color characteristics in the study. Warriss et al. (1987) reported that $\mathrm{pH}$ determines drip loss in porcine muscle. Muscle water is driven towards the extracellular spaces at lower $\mathrm{pH}$ values, which leads to lower pork WHC. In this study, $\mathrm{pH}_{24 \mathrm{~h}}$ was negatively correlated with drip loss at $24 \mathrm{~h}$ post-mortem $(\mathrm{r}=-0.52, \mathrm{p}<0.01)$, which indicated that the decline $\mathrm{pH}$ values in $\mathrm{LD}$ muscle of $\mathrm{H} 30$ pigs were in accordance with the poor WHC in the study.

Effects of constant heat stress on carnosine synthetase mRNA expression and carnosine content of longissimus dorsi muscle in finishing pigs

Carnosine is a naturally-occurring dipeptide that is synthesized by the CARNS1 from $\beta$-alanine and L-histidine. It is widely accepted that carnosine acts as a potent endogenous antioxidant in its function of metal chelation, hydrogen donorship and oxygen free-radical scavenging. Supplementation of carnosine $(100 \mathrm{mg} / \mathrm{kg}$ diet $)$ results in reduction of muscle MDA concentration in finishing pigs (Ma et al., 2010). It was reported that carnosine is an effective agent to decrease prooxidant status in brain of oxidative stress rats (Kalaz et al., 2012).

Carnosine synthetase has been isolated from chicken sternal muscle and human skeletal and heart muscles (Bulygina et al., 1995). In this study, the down-regulation of CARNS1 mRNA expression was in accordance with the decreased muscle carnosine content in H30 pigs. Higher muscle carnosine level and CARNS1 mRNA expression were observed in $\mathrm{H} 30$ pigs than PF, revealing that these remarkable influences were caused by direct effects of high ambient temperature stress.

Carnosine content of $\mathrm{H} 30$ pigs $(4.98 \mathrm{mg} / \mathrm{g}$ ) was significantly lower than that of CON $(5.62 \mathrm{mg} / \mathrm{g})$ and $\mathrm{PF}$ (5.58 mg/g). On the other hand, Manhiani et al. (2011) reported that carnosine content in breast of short-term (15 min) stressed birds $(17.39 \mathrm{mg} / \mathrm{g})$ was ten times higher than that of non-stressed birds $(1.85 \mathrm{mg} / \mathrm{g})$. Additionally, carnosine content of thigh tissue of stressed birds $(21.25$ $\mathrm{mg} / \mathrm{g}$ ) was approximately 2-fold higher than that of nonstressed birds (11.10 mg/g). In horses, Dunnett et al. (2002) found higher plasma carnosine concentration at 5 to $30 \mathrm{~min}$ and lower carnosine concentrations at $120 \mathrm{~min}$ postexercise; however, carnosine values returned to normal after $1 \mathrm{~d}$. Differences in muscle carnosine content among animals exposed to stress may be accounted for by the difference in species, stress duration time and intensity. It was possible that the content of carnosine in skeletal muscle of birds and plasma of horses increased under short-time stress and then may have decreased over time, similar to the situation in LD muscle of finishing pigs suffering from constant heat stress.

\section{Effects of constant heat stress on antioxidant capacity of longissimus dorsi muscle in finishing pigs}

According to previous reports, heat stress accelerates the oxidation of muscle tissue (Wang et al., 2009), resulting in a shift in the pro-oxidant/antioxidant balance (Lin et al., 2006). The MDA is a marker of mitochondrial and muscle lipid peroxidation, CAT and SOD are antioxidant parameters.

Higher MDA level and lower enzyme activity of SOD, CAT in LD muscle of $\mathrm{H} 30$ pigs were obtained than CON in this study. The MDA levels of LD muscle in $\mathrm{H} 30$ pigs were higher than PF, while CAT activities in $\mathrm{H} 30$ muscle were lower than PF, showing the direct effects of constant high ambient temperature lead to oxidative stress in LD muscle of finishing pigs. It has been reported that weaning stress enhances MDA levels, decreases SOD activity in serum of piglets (Zhu et al., 2012). Increased MDA concentration and decreased SOD activity were observed after 48 hours oxidative stress in porcine kidney cells (Chen et al., 2013). Azad et al. (2010) and Mahmoud et al. (2003) demonstrated that constant heat stress results in higher MDA levels in skeletal muscle of broiler chickens. Addition of hexachlorocyclohexane to feedstuff reduced liver SOD and serum CAT activity, increased serum MDA in 
growing/finishing pigs (Wang et al., 2006). Hepatic and brain CAT activities decrease in rats exposed to chronic cold stress (Kalaz et al., 2012).

The MDA is generally used as a biomarker for radicalinduced damage and endogenous lipid peroxidation, it is implied that the pro-oxidant/antioxidant balance is disrupted with higher MDA levels of LD muscle in H30 pigs. The SOD catalyzes the conversion of superoxide to hydrogen peroxide and functions in conjunction with CAT to convert hydrogen peroxide into water and molecular oxygen (Finkel and Holbrook, 2000). The decreased antioxidant capacity (SOD and CAT) and enhanced lipid peroxidation (MDA) in LD muscle of $\mathrm{H} 30$ pigs indicated an oxidative stress under constant high temperature condition.

Carnosine may affect meat quality of longissimus dorsi muscle in finishing pigs through antioxidant capacity under constant heat stress

Carnosine is a potent ROS scavenger, which inhibits lipid peroxidation and protein damage (Namgung et al., 2010). Carnosine supplementation decreases MDA levels in both liver and brain tissues of constant cold-stressed rats (Kalaz et al., 2012). In this study, muscle MDA content was negatively correlated with carnosine content $(r=-0.52$, $\mathrm{p}<0.01$ ), while muscle CAT activities were positively correlated with carnosine content $(r=0.43, p<0.05)$. These results revealed that reduced muscle carnosine content was positively correlated with the oxidant status of muscle tissue.

In this study, low antioxidant capacity of muscle tissue was associated with poor meat quality. There was a significant positive correlation between muscle MDA content and shear force $(r=0.73, p<0.01)$, while a significant negative correlation was obtained between CAT activity and shear force $(r=-0.62, \mathrm{p}<0.05)$, indicating that less tender meat has higher oxidant status. Zhang et al. (2012) reported that lower $a^{*}$ values in heat-exposed birds were due to oxidized myoglobin pigments, which is consistent with the positive correlation $(\mathrm{r}=0.41, \mathrm{p}<0.1)$ between $\mathrm{a}^{*}$ values at $24 \mathrm{~h}$ and CAT activity obtained in this study. The MDA content was positively correlated with $\mathrm{L}^{*}$ values at $24 \mathrm{~h}$ post-mortem $(\mathrm{r}=0.69, \mathrm{p}<0.01)$; CAT activity was negatively correlated with $L^{*}$ values at $24 \mathrm{~h}$ postmortem $(r=-0.64, p<0.01)$, which suggests that paler meat color characteristics were accompanied with lipid peroxidation in heat-stressed pigs.

The effects of carnosine on meat quality have been reported. Ma et al. (2010) reported that the addition of 100 $\mathrm{mg}$ carnosine per $\mathrm{kg}$ diet increases $\mathrm{pH}$ values of muscle at $45 \mathrm{~min}, 24 \mathrm{~h}$, and $48 \mathrm{~h}$ post-mortem in LD muscle of finishing pigs. Cheng et al. (2013) and Das et al. (2006) reported that carnosine increases $\mathrm{pH}$ values of pre-cooked pork patties and ground buffalo meat. Carnosine supplementation increases the redness of meat in finishing pigs (Ma et al., 2010) and ground beef (Sanchez-Escalante et al., 2003). Decker et al. (1990) reported that carnosine is effective in inhibiting myoglobin oxidation in salted, frozen, ground pork. Even though there were no significant correlations between muscle carnosine content and $\mathrm{a}^{*}$ values in this study, there were significant negative correlations between $\mathrm{L}^{*}$ values (at $45 \mathrm{~min}$ and $24 \mathrm{~h}$ postmortem) and carnosine content $(\mathrm{r}=-0.45, \mathrm{p}<0.05$ and $\mathrm{r}=$ $-0.50, \mathrm{p}<0.05$, respectively). A significant negative correlation was obtained between muscle carnosine content and drip loss at $48 \mathrm{~h}$ post-mortem $(\mathrm{r}=-0.58, \mathrm{p}<0.01)$; pigs exposed to constant heat stress have lower carnosine content and higher drip loss in LD muscle, similar to the findings of Ma et al. (2010), who observed decreased drip loss at $48 \mathrm{~h}$ post-mortem in pigs of carnosine addition.

A lot of researches above verified that carnosine supplementation improves meat quality. The correlation among lower carnosine content and decreased antioxidant capacity, and the relationship among decreased antioxidant capacity and poor meat quality were observed in the study. Therefore, peroxidation and poor meat quality in heatstressed pigs may be attributed to lower carnosine content.

In conclusion, the results confirmed that constant heat stress results in lower muscle $\mathrm{pH}, \mathrm{a}^{*}$ values, and tenderness, and higher drip loss and $\mathrm{L}^{*}$ values. The meat quality is associated with increased MDA content and decreased antioxidant capacity (CAT and SOD) in LD muscle of chronically heat-stressed pigs, which might be attributed to the reduction in meat carnosine content.

\section{ACKNOWLEDGMENTS}

This study was supported by grants from the National Key Basic Research Program of China (National 973 Project) (2012CB124706), Key Project in the National Science \& Technology Pillar Program (2012BAD39B0202) and The Agricultural Science and Technology Innovation Program (ASTIP-IAS07). The authors greatly appreciate Dr Yanjun Cui, Mr Zhenghui Cao and Chunhe Yang for their skilled help in meat sampling and in several laboratory analyses. The authors would like to thank the reviewers for their valuable comments and suggestions.

\section{REFERENCES}

Abril, M., M. M. Campo, A. Önenç, C. Sanudo, P. Albertí, and A. I. Negueruela. 2001. Beef colour evolution as a function of ultimate $\mathrm{pH}$. Meat Sci. 58:69-78.

Aebi, H. 1984. Catalase in vitro. Methods Enzymol. 105:121-126.

Antonopoulou, E., E. Kentepozidou, K. Feidantsis, C. Roufidou, S. Despoti, and S. Chatzifotis. 2013. Starvation and re-feeding affect Hsp expression, MAPK activation and antioxidant enzymes activity of European Sea Bass (Dicentrarchus labrax). 
Comp. Biochem. Physiol. A. Mol. Integr. Physiol. 165:79-88.

Azad, M. A. K., M. Kikusato, T. Maekawa, H. Shirakawa, and M. Toyomizu. 2010. Metabolic characteristics and oxidative damage to skeletal muscle in broiler chickens exposed to chronic heat stress. Comp. Biochem. Physiol. A. Mol. Integr. Physiol. 155:401-406.

Bulygina, E. R. and G. G. Kramarenko. 1995. Isolation of carnosine synthetase from animal and human muscles. Vopr. Med. Khim. 41:27-30.

Chen, X., F. Ren, J. Hesketh, X. Shi, J. Li, F. Gan, and K. Huang. 2013. Interaction of porcine circovirus type 2 replication with intracellular redox status in vitro. Redox Rep. 18:186-192.

Cheng, J. H., S. T. Wang, and H. W. Ockerman. 2013. Quality preservation of reduced sodium pork patties: Effects of antioxidants on color and lipid stability. J. Sci. Food Agric. 93: 2959-2962.

Cheng, Q. and D. W. Sun. 2008. Factors affecting the water holding capacity of red meat products: A review of recent research advances. Crit. Rev. Food Sci. Nutr. 48:137-159.

Chulayo, A. Y. and V. Muchenje. 2013. The Effects of preslaughter stress and season on the activity of plasma creatine kinase and mutton quality from different sheep breeds slaughtered at a smallholder Abattoir. Asian Australas. J. Anim. Sci. 26:1762-1772.

Das, A. K., A. S. R. Anjaneyulu, and S. Biswas. 2006. Effect of carnosine preblending on the quality of ground buffalo meat. Food Chem. 97:531-538.

Decker, E. A. and H. Faraji. 1990. Inhibition of lipid oxidation by carnosine. J. Am. Oil Chem. Soc. 67:650-652.

Dunnett, M., R. C. Harris, C. E. Dunnett, and P. A. Harris. 2002. Plasma carnosine concentration: Diurnal variation and effects of age, exercise and muscle damage. Equine. Vet. J. (Suppl. 34):283-287.

Finkel, T. and N. J. Holbrook. 2000. Oxidants, oxidative stress and the biology of ageing. Nature 408:239-247.

Imik, H., H. Ozlu, R. Gumus, M. A. Atasever, S. Urcarand, and M. Atasever. 2012. Effects of ascorbic acid and a-lipoic acid on performance and meat quality of broilers subjected to heat stress. Br. Poult. Sci. 53:800-808.

Jurie, C., I. Ortigues-Marty, B. Picard, D. Micol, and J. F. Hocquette. 2006. The separate effects of the nature of diet and grazing mobility on metabolic potential of muscles from Charo-lais steers. Livest. Sci. 104:182-192.

Kalaz, E. B., B. Evran, S. Develi-İs, P. Vural, S. Doğru-Abbasoğlu, and M. Uysal. 2012. Effect of carnosine on prooxidantantioxidant balance in several tissues of rats exposed to chronic cold plus immobilization stress. J. Pharmacol. Sci. 120:98-104.

Kauffman, R. G., G. Eikelenboom, P. G. van der Wal, G. Merkus, and M. Zaar. 1986. The use of filter paper to estimate drip loss of porcine musculature. Meat Sci. 18:191-200.

Küchenmeister, U., G. Kuhn, and K. Ender. 2000. Seasonal effects on $\mathrm{Ca}^{2+}$ transport of sarcoplasmic reticulum and on meat quality of pigs with different malignant hyperthermia status. Meat Sci. 55:239-245.

Lin, H., J. Buyse, and E. Decuypere. 2006. Acute heat stress induces oxidative stress in broiler chickens. Comp. Biochem. Physiol. A. Mol. Integr. Physiol. 144:11-17.

Lu, Q. P., J. Wen, and H. F. Zhang. 2007. Effect of chronic heat exposure on fat deposition and meat quality in two genetic types of chicken. Poult. Sci. 86:1059-1064.

Lu, Q. P., H. F. Zhang, Q. W. Liu, and S. J. Liu. 2010. The effect of high ambient temperature on muscle fiber characteristics and meat quality in growing pig. In: Proceedings of the Sixth National Conference on Feed Nutrition, Yangling, China. pp. 542-543.

Ma, X. Y., Z. Y. Jiang, Y. C. Lin, C. T. Zheng, and G. L. Zhou. 2010. Dietary supplementation with carnosine improves antioxidant capacity and meat quality of finishing pigs. J. Anim. Physiol. Anim. Nutr (Berl). 94:e286-e295.

Mahmoud, K. Z. and F. W. Edens. 2003. Influence of selenium sources on age-related and mild heat stress-related changes of blood and liver glutathione redox cycle in broiler chickens (Gallus domesticus). Comp. Biochem. Physiol. B. Biochem. Mol. Biol. 136:921-934.

Mancini, R. A. and M. C. Hunt. 2005. Current research in meat color. Meat Sci. 71:100-121.

Manhiani, P. S., J. K. Northcutt, I. Han, W. C. Bridges, T. R. Scott, and P. L. Dawson. 2011. Effect of stress on carnosine levels in brain, breast, and thigh of broilers. Poult. Sci. 90:2348-2354

McKee, S. R. and A. R. Sams. 1997. The effect of seasonal heat stress on rigor development and the incidence of pale, exudative turkey meat. Poult. Sci. 76:1616-1620.

Morales, A., F. Grageola, H. García, N. Arce, B. Araiza, J. Yáñez, and M. Cervantes. 2014. Performance, serum amino acid concentrations and expression of selected genes in pair-fed growing pigs exposed to high ambient temperatures. J. Anim. Physiol. Anim. Nutr. (Berl). doi: 10.1111/jpn.12161.

Namgung, N., D. H. Shin, S. W. Park, and I. K. Paik. 2010. Effects of supplementary blood meal on carnosine content in the breast meat and laying performance of old hens. Asian Australas. J. Anim. Sci. 23:946-951.

Ōyanagui, Y. 1984. Reevaluation of assay methods and establishment of kit for superoxide dismutase activity. Anal. Biochem. 142:290-296.

Pérez, M. P., J. Palacio, M. P. Santolaria, M. C. Aceña, G. Chacón, M. Gascón, J. H. Calvo, P. Zaragoza, J. A. Beltran, and S. García-Belenguerd. 2002. Effect of transport time on welfare and meat quality in pigs. Meat Sci. 61:425-433.

Placer, Z. A., L. L. Cushman, and B. C. Johnson. 1966. Estimation of product of lipid peroxidation (malonyldialde-hyde) in biochemical systems. Anal. Biochem. 16:359-364.

Rosenvold, K. and H. J. Andersen. 2003. The significance of preslaughter stress and diet on color and colour stability of pork. Meat Sci. 63:199-209.

Salmi B., L. Trefan, L. Bünger, A. Doeschl-Wilson, J. P. Bidanel, C. Terlouw, and C. Larzul. 2012. Bayesian meta-analysis of the effect of fasting, transport and lairage times on four attributes of pork meat quality. Meat sci. 90:584-598.

Sanchez-Escalante, A., D. Djenane, G. Torrescano, B. Giménez, J. A. Beltrán, and P. Roncalés. 2003. Evaluation of the antioxidant ability of hydrazine-purified and untreated commercial carnosine in beef patties. Meat Sci. 64:59-67.

Schmittgen, T. D. and K. J. Livak. 2008. Analyzing real-time PCR data by the comparative $\mathrm{C}(\mathrm{T})$ method. Nat. Protoc. 3:11011108 .

Science and Technology Ministry of China. 2006. The guiding suggestion about treating experimental animals amicablely. 
No.398 Document.

Velasco, V. and P. Williams. 2011. Improving meat quality through natural antioxidants. Chil. J. Agric. Res. 71:313-322.

Wang, F., Z. R. Xu, and J. H. Su. 2006. Effect of $\mathrm{HCH}$ contamination of diet on the growth performance and immune and antioxidant ability in growing/finishing pigs. Vet. Res. Commun. 30:645-654.

Wang, R. R., X. J. Pan and Z. Q. Peng. 2009. Effects of heat exposure on muscle oxidation and protein functionalities of pectoralis majors in broilers. Poult. Sci. 88:1078-1084.
Warriss, P. D. and S. N. Brown. 1987. The relationship between initial $\mathrm{pH}$, reflectance and exudation in pig muscle. Meat Sci. 20:65-72.

Zhang, Z. Y., G. Q. Jia, J. J. Zuo, Y. Zhang, J. Lei, L. Ren, and D. Y. Feng. 2012. Effects of constant and cyclic heat stress on muscle metabolism and meat quality of broiler breast fillet and thigh meat. Poult. Sci. 91:2931-2937.

Zhu, L. H., K. L. Zhao, X. L. Chen, and J. X. Xu. 2012. Impact of weaning and an antioxidant blend on intestinal barrier function and antioxidant status in pigs. J. Anim. Sci. 90:2581-2589. 